\title{
Innovation Practices at Makerspaces in Egypt, Tunisia and Morocco
}

\section{Nagham ElHoussamy}

Associate Director for Research, Middle East and Africa, Access to Knowledge for Development Center (A2K4D), School of Business, The American University in Cairo (AUC); and North Africa Hub Coordinator, Open African Innovation Research (Open AIR) network (iD) https://orcid.org/0000-0002-8904-3191

\section{Nagla Rizk}

Professor of Economics, and Founding Director, Access to Knowledge for Development Center (A2K4D), School of Business, The American University in Cairo (AUC); and Steering Committee Member, Open African Innovation Research (Open AIR) network iD https://orcid.org/0000-0002-2126-1096

\begin{abstract}
This article sets out findings from research exploring approaches to innovation at makerspaces in Egypt, Tunisia, and Morocco. Based on interviews with individuals involved in makerspaces in each country-seven spaces in Egypt, two in Tunisia, and one in Morocco-we provide findings on the origins and general characteristics of the spaces, as well as findings on five core themes that emerged from the interviews: knowledge-sharing; innovation and product development; openness, collaboration, and innovation ownership; attitudes towards intellectual property (IP); and scaling.
\end{abstract}

\section{Keywords}

maker movement, innovation, entrepreneurship, knowledge-sharing learning, skills development, innovation ownership, intellectual property (IP), scaling, Egypt, Tunisia, Morocco

\section{Acknowledgements}

The research for this article was carried out under the auspices of the Open African Innovation Research (Open AIR) network, which is a partnership between The American University in Cairo, the Nigerian Institute of Advanced Legal Studies, Strathmore University in Nairobi, the University of Cape Town, the University of Johannesburg, and the University of Ottawa. The authors acknowledge the support provided for this research by Open AIR, the Social Sciences and Humanities Research Council (SSHRC) of Canada, the International Development Research Centre (IDRC), and the UK Department for International Development (DFID). The views expressed in this work are those of the authors and do not necessarily represent those of the research funders. The authors also acknowledge the research assistance provided by the following researchers at the Access to Knowledge for Development Center (A2K4D) at The American University in Cairo: Sarah E1 Saeed, Mai El Khamisi, Mohamed Hosny, Farida Kamel, and Nancy Salem. The authors are also thankful to the interviewees for sharing their views on the issues addressed, 
and are grateful for the comments received, through the internal review processes of the Open AIR network, from Prof. Erika Kraemer-Mbula of the University of Johannesburg and Dr. Isaac Rutenberg of Strathmore University. This article draws on elements of a working paper (ElHoussamy \& Rizk, 2018).

DOI: $\underline{\text { https://doi.org/10.23962/10539/30357 }}$

\section{Recommended citation}

ElHoussamy, N., \& Rizk, N. (2020). Innovation practices at makerspaces in Egypt, Tunisia and Morocco. The African Journal of Information and Communication (AJIC), 26,1-25. https://doi.org/10.23962/10539/30357

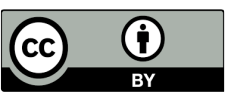

This article is licensed under a Creative Commons Attribution 4.0 International (CC BY 4.0) licence: https://creativecommons.org/licenses/by/4.0

\section{Introduction}

Amidst the socioeconomic and political flux present in North Africa since the Arab uprisings that swept across the region, starting in early 2011, a number of innovation spaces have emerged in Egypt, Tunisia, and Morocco in which makers, hackers, and entrepreneurs can meet and collaborate. While alternative modes of innovation and creation have historically been neglected by a majority of African policymakers due to the "unconventional nature of their enterprises", recent years have witnessed a sharp increase across the continent in civic participation in - and researcher and policymaker interest in - the maker movement (Ekekwe, 2015). The movement is especially significant in African contexts, because it empowers citizens to use their local expertise and skills and translate this know-how into solution-oriented innovation that targets problems that exist in their daily lives, such as problems of access to clean water, energy, health care, and food (Ekekwe, 2015).

The maker movement has been called a "new industrial revolution"(Anderson, 2012). Sharing is at the core of this revolution, in contrast to the predominance of industrial secret-keeping in the past. This sharing serves to fulfil the promise of the public good characteristics of knowledge, notably non-rivalry, where the value of knowledge increases rather than diminishes with use and sharing. Makerspaces, which provide tools to entrepreneurs and other individuals, also provide access to technologies. This presents youth and potential entrepreneurs with opportunities to access sophisticated technologies and means of production at low costs. One of the unique attributes of the maker movement is that the creative process of making is shared with others, allowing others to improve and build upon innovations. This is similar in concept to the free and open source software (FOSS) movement, whereby codes are freely available for individuals to build on and improve. 
In our study, we aimed to gain insights into how the maker movement is unfolding in three North African countries: Egypt, Tunisia, and Morocco. In particular, we were interested in the modes of innovation, knowledge-sharing, knowledge management, product development, and scaling present in the 10 spaces we studied. This study aims to provide an initial North African contribution to the emerging body of empirical research on the maker movement in Africa (see Armstrong et al., 2018; De Beer et al., 2017; Kraemer-Mbula \& Armstrong, 2017).

\section{Study background and context}

Makerspaces are physical spaces with fabrication tools where individuals can design, prototype, and create manufactured items for a variety of purposes. Makerspaces provide individuals with free or low-cost access to shared equipment, training in use of the equipment, and participation in a collaborative community. The collaborative community allows for peer-to-peer knowledge exchange and sharing, whereby a maker who is knowledgeable about one tool can aid other innovators, and vice versa: "One capable craftsman with a [...] 3D printer can provide improved manufacturing services and specialized components for hundreds of artisans; similarly, a technically literate artisan with a computer [...] can assist hundreds of [...] mechanics." (Waldman-Brown et al., 2014, p. 13). According to Good (2013), the spaces transform collective knowledge into a physical or digital product. This final product keeps getting revised and improved upon and the evolving process of that product reflects the learning that takes place in a makerspace.

The maker movement phenomenon has been on the rise in developing countries, in line with efforts to address local problems in innovative ways at low cost. We can draw a parallel between makers and "lead users", a term coined by Von Hippel (1986) to describe those who identify needs for products before their market demand arises. Lead users generally start firms based on the solutions they develop, similar to makers who often create products to solve problems affecting them personally or affecting the communities in which they live.

Typical fabrication tools found in a makerspace are 3D printers, laser cutters, milling machines, $\mathrm{CNC}$ routers, engraving machines, soldering tools, and woodworking tools. Makerspaces benefit from open source appropriate technology (OSAT), which encourages innovation by using mostly open designs and blueprints. With particular importance in developing-world settings, OSAT allows for imported technologies to be adapted, altered to meet local developmental needs, and produced at low cost (see King et al., 2014). For example, the RepRap open design 3D printer, which is often found in makerspaces, is an open source desktop 3D printer capable of printing plastic objects. The printer is portable, and has the ability to affordably custom manufacture a wide arrange of items, based on free-of-charge open source design files (King et al., 2014). 
Van Holm (2017), situating makers within the practice of entrepreneurship, proposes that makerspaces "aid in the creation of new enterprises" and "offer an environment supportive of innovation" (Van Holm, 2017, p. 25). Significantly, however, Van Holm argues that driving entrepreneurship is in fact not the maker movement's greater strength. Rather, Van Holm argues, the movement's greatest power lies in its potential, through its "openness and flexibility", to engender community development, education, and sustainable development (Van Holm, 2017, p. 30).

Makerspaces provide an open collaborative space that is inviting to entrepreneurs who want to innovate, and also to those more focused on the "making" without having an overtly entrepreneurial mindset. Makerspaces provide an opportunity for innovation to occur in a setting of sharing and openness. For those with an entrepreneurial mindset, makerspaces offer collaborative opportunities and tools to develop ideas from inception phase to market launch. This emerging phenomenon of collaborative and digital fabrication within the African maker movement has the potential to transform dynamics in a variety of industries on the continent (see Ekekwe, 2015).

Makerspaces and their users exhibit attributes of what can be referred to as a "community of practice" (see Sheridan et al., 2014; Wenger et al., 2002). Communities of practice, according to Wenger et al. (2002, p. 4), "are groups of people who share a concern, a set of problems, or a passion about a topic, and who deepen their knowledge and expertise in this area by interacting on an ongoing basis". Within a makerspace, there tends to be a formal learning component along the lines of the traditional teacher-to-student model, and at the same time a strong, non-hierarchical, informal element that allows users to exchange skills, experiences, and ideas. This prioritisation of peer-to-peer knowledge-sharing is one of the key, transformational characteristics of the maker movement. In spite of the differences in the scale of makerspace projects, participants, and funding, all makerspaces share an ethos of using the creative process to share knowledge.

Several of the makerspaces we identified in North Africa, and included in our study, are fabrication laboratories (fab labs), which are makerspaces following specifications set out by the international Fab Foundation at the Massachusetts Institute of Technology (MIT) Center for Bits and Atoms. The Fab Foundation was established in 2009 to support the development of an international network of fab labs designed to

provide access to the tools, the knowledge and the financial means to educate, innovate and invent using technology and digital fabrication to allow anyone to make (almost) anything, and thereby creating opportunities to improve lives and livelihoods around the world. (Fab Foundation, n.d.) 
According to the Fab Foundation, a fab lab is a technical prototyping platform for innovation and invention, providing stimulus for local entrepreneurship. A fab lab is also a platform for learning and innovation: a place to play, to create, to learn, to mentor, and to invent (Fab Foundation, n.d.).

\section{Research design}

We undertook both desk research and exploratory fieldwork, with our main method of data collection during fieldwork consisting of semi-structured interviews based on an interview protocol (see Appendix). We deemed exploratory fieldwork to be the most appropriate method, given the limited data available on the maker movement in North Africa. The interview sample consisted of 16 individuals: 11 people from seven makerspaces in Egypt, two people from two makerspaces in Tunisia, four people from one makerspace in Morocco, and a person connected to Maker Faire Cairo. We used purposive sampling to select the makerspaces and interviewees included in the study, with the choices somewhat dependent on our established contacts in each country. All the interviewees agreed that their names could be used in our publications based on the research.

As per the interview protocol, we asked the interviewees about the following in respect of their respective makerspaces:

- the space's core characteristics (establishment, operational model, tools, links to other spaces and/or enterprises);

- creative processes, knowledge-sharing, innovation, learning, skills development, users;

- dynamics in terms of intellectual property (IP) and informality;

- scaling of innovations and products; and

- measuring innovation.

The interviews were audio-recorded and the transcripts analysed qualitatively, with the findings organised in terms of the main themes that emerged in the interviewees' statements. The 10 makerspaces included in the study are listed in Table 1. 
Table 1: The 10 makerspaces studied

\begin{tabular}{|c|c|c|}
\hline Name & Location & URL \\
\hline Fab Lab Egypt & Cairo & https://fablabegypt.com \\
\hline Qafeer Makerspace & Cairo & $\frac{\text { https://www.facebook.com/qafeermaker- }}{\text { space/ }}$ \\
\hline $\begin{array}{l}\text { Fab Lab in New Cairo } \\
\text { (FLiNC) }\end{array}$ & Cairo & $\begin{array}{c}\text { https://www.fablabs.io/labs/fablabnew- } \\
\underline{\text { cairo }}\end{array}$ \\
\hline FabLab AUC & Cairo & https://www.facebook.com/FabLabAUC/ \\
\hline Karakeeb Makerspace & Alexandria & https://www.facebook.com/karakeeb.co/ \\
\hline icealex & Alexandria & $\underline{\text { http://icealex.com }}$ \\
\hline $\begin{array}{c}\text { Alex } \\
\text { Hackerspace }\end{array}$ & Alexandria & $\frac{\text { https://www.facebook.com/alexhacker- }}{\text { space/ }}$ \\
\hline FabLab ENIT & Tunis & https://www.facebook.com/FabLabENIT/ \\
\hline LEVEL1 & Tunis & http://www.level1hub.com/ \\
\hline Fablab Casablanca & Casablanca & $\begin{array}{l}\text { https://www.facebook.com/FABLAB. } \\
\text { CASA/ }\end{array}$ \\
\hline
\end{tabular}

\section{Findings on the makerspaces' core characteristics}

\section{Fab Lab Egypt}

Fab Lab Egypt was launched in 2012, operating out of a garage. It was the first official fab lab to open in the country (Fab Lab Egypt, n.d.), and its initial model was purely educational and focused on providing programmes and workshops. In 2016, it moved to a new and larger location to become a platform to empower makers, to host start-ups, and to draw in individuals not involved in the maker movement. It provides an open collaborative makerspace equipped with digital fabrication and prototyping machines and tools, and it offers business-to-business (B2B) services that provide a source of revenue for the operation of the lab. At the time of our research, the space was hosting three resident start-ups. Fab Lab Egypt has been self-funded since its inception. 
The makerspace directed its $\mathrm{B} 2 \mathrm{~B}$ work towards its main vision of spreading the maker culture by partnering with mobile operator Orange Egypt to create minifab labs in Egyptian governorates. Fab Lab Egypt is the caretaker of several other makerspaces throughout Egypt and also collaborates widely. Their rationale for collaboration is that they aim to spread the maker culture in the country, rather than monopolise the maker market.

The creation of Fab Lab Egypt was followed, in 2013, by the opening of Qafeer Makerspace in the 6th of October City district, and, in 2015, by the opening of Fab Lab in New Cairo (FLiNC). These makerspaces were intended to target citizens in both the west and the east of Cairo (Fablabs.io, n.d.). When criticised by other emerging makerspaces in Egypt for having a "monopoly" on workshops offered to the community, Fab Lab Egypt suspended this service and began directing any workshop requests to other makerspaces in the country (El Safty interview). Fab Lab Egypt collaborates with other makerspaces in assisting new spaces to open up. Fab Lab Egypt also organises the annual Maker Faire Cairo, bringing together makers from different parts of Egypt to showcase their work and to collaborate. For the smaller spaces unable to afford a booth at the Maker Faire, Fab Lab Egypt waives the fees to enhance the visibility of these smaller makerspaces in the maker community. Fab Lab Egypt strongly believes that the closure of any makerspace has a negative impact on the maker movement in Egypt as a whole.

\section{Qafeer Makerspace}

Founded in Cairo in 2013 and affiliated with the Fab Foundation, Qafeer Makerspace closed in 2019 due to financial difficulties, but it was in operation at the time of our research and we interviewed its director. It functioned mainly as a community-run makerspace, using the meeting room of an existing co-working space, Qafeer Labs. The founders of Qafeer Labs established the makerspace through an online crowd-funding campaign on Zoomaal (n.d.) that managed to raise more than USD16,000. It was the first makerspace established in Cairo's 6th of October district, and it collaborated with other makerspaces so as to have access to tools that it lacked. Although it is open to anyone, it offered few formal training sessions on the use of its tools and thus relied on attracting relatively experienced makers (El Zoughby interview).

\section{Fab Lab in Nerw Cairo (FLiNC)}

FLiNC was launched in late 2015—with the help of Fab Lab Egypt—by Giza Systems, a systems integrator in the Middle East and North Africa that assists businesses in asset-intensive industries to streamline their operations. FLiNC, located at the Giza Systems offices, is fully funded by the private sector, specifically Giza Systems and EMC2 Dell, as part of the corporate social responsibility (CSR) programmes of both entities. Being associated with a private company brought advantages in terms of finding financial resources to create the space (El Raffei interview). Accredited 
by the global Fab Foundation, FLiNC is registered as a non-governmental organisation (NGO), under the Giza Foundation umbrella, and although it is located on the premises of a private company, FLiNC aims to serve the maker community at large and to expand its maker base. It offers regular workshops to the maker community in Egypt, and collaborates with other spaces in competitions and events. For example, together with Fab Lab Egypt, FLiNC co-hosts FabLab on Wheels (FLoW), a mobile fab lab created to improve accessibility. FLoW is located inside a bus, which mostly tours governorates outside Cairo and Alexandria where virtually no makerspaces exist. FLoW volunteers help makers to use the tools provided in the space, and also discuss the viability of potential products that makers want to create (FabLab on Wheels, n.d.).

\section{FabLab AUC}

Located at The American University in Cairo (AUC) and affiliated to the Fab Foundation, FabLab AUC officially began operating in April 2017 for AUC students (AUC, 2017). Two engineering students at AUC launched FabLab AUC, and it is the only university-based makerspace in Egypt that is included in this research. AbdelRahman Shalaby, one of the co-founders of FabLab AUC, was first introduced to the concept of a makerspace when he interned at Fab Lab Egypt. He wanted to bring this concept to AUC students, so he partnered with another student, Mohamed Ragab, to create the space. FabLab AUC was built from scratch in an existing lab at AUC's New Cairo Campus. Shalaby and Ragab pitched the idea to the Mechanical Engineering Department, and received moral encouragement but no financial support. They then turned to different entities on campus to solicit the necessary funds to open the makerspace. It now receives financial support from various AUC entities, including the Mechanical Engineering Association (Shalaby and Ragab interview). FabLab AUC is a rapid prototyping working space, equipped (at the time of our research) with a 3D printer, a laser cutter, a four-axis CNC milling machine, and a variety of other mechanical and electronic tools. FabLab AUC is a non-profit entity, and while it charges a symbolic fee for the use of the space, all money is poured back into the lab and used to buy materials and to support projects.

\section{Karakeeb Makerspace}

Located in Alexandria, community-based Karakeeb Makerspace was established in 2013 in the city's Jesuit Cultural Center. It is a mini-makerspace that attempts to spread technology and knowledge of digital fabrication, as well as the culture of making, to people with non-engineering backgrounds. The space is completely volunteer-based and self-funded; it also relies on non-financial donations in the form of machines and tools. Karakeeb collaborates closely with Fab Lab Egypt and icealex, a second makerspace in Alexandria, and participates in Egypt's annual Maker Faire in Cairo. Karakeeb was founded as the result of a partnership between two Egyptian 
youths and a pastor. The pastor first provided Mina Effat and Rabab Hassan with a $2 \times 2$-metre room to set up the makerspace in the Jesuit Cultural Center. A few months later, a slightly bigger room, $2 \times 5$ metres, became available and Karakeeb's co-founders began to search for funds. They received the money for their first machine from a friend of the pastor, who asked his wedding guests to give gifts in the form of monetary contributions to Karakeeb (Effat and Hassan interview). Karakeeb aims to support start-ups and works with local NGOs to spread the maker culture, especially targeting underprivileged youth. The space maintains close ties with the Egyptian maker community through participation in events and workshops.

\section{icealex}

icealex (Innovation, Collaboration and Entrepreneurship Alexandria) is part of the international ICE hubs network based in Germany, which has branches in Ethiopia, Egypt, and Germany. The ICE hubs focus on helping developing countries create environmentally friendly and sustainable products. The makerspace was built in 2013 by three youths with the help of the maker community and crowd-funding. icealex encourages an open source collaborative culture. The space holds monthly workshops to transfer various technical skills to makers, in addition to an entrepreneurship programme to help interested makers develop their innovations and become more market-driven. There is a co-working area within the space, as a secondary activity to the makerspace. icealex sources income from corporate users to subsidise services for start-ups and students (Bastawy interview). icealex participates in the annual Cairo Maker Faire. In January 2017, its sister branch, icecairo, shut down due to the rising costs of products necessary for the operation of the makerspace and the increasing economic challenges in Egypt generally (icecairo, n.d.).

\section{Alex Hackerspace}

Also in Alexandria is Alex Hackerspace, a community-run makerspace established in 2015, using only self-funding. Founder Amr El Shaer came up with the idea for Alex Hackerspace in 2010, but it was not until 2015 that he co-founded it with his partner. In 2014, El Shaer was awarded a place in the US Department of State's International Visitor Leadership programme, a professional exchange programme that allowed him to tour the US for 22 days, examining different makerspace models. Upon his return, El Shaer quit his full-time job and focused on creating Alex Hackerspace (El Shaer interview). It provides a variety of tools for makers at a low cost, as well as consultancy services and courses on hands-on creation of different innovations and products. The space is completely self-financed by its founders, both in terms of machinery and operational costs. Alex Hackerspace caters both to makers with an engineering background, as well as to makers new to the idea of fabrication and hands-on innovation. They maintain close ties with the Egyptian maker community by co-hosting workshops and participating in events. 


\section{FabLab ENIT}

FabLab ENIT, in the Tunisian capital Tunis, was established in the National Engineering School of Tunis (ENIT) in 2013 by a professor, as a collaboration initiative with other professors from Europe to bring innovation modules to universities across North Africa. The goal of the makerspace is to give students and faculty equal access to different modes of production. FabLab ENIT does not charge any subscription fee for using the space. Users pay for the costs of the materials they use. The space is student-run and is accredited by the Fab Foundation. When first established, FabLab ENIT was funded by the European Union (EU) as part of an ongoing collaboration between ENIT and the EU, and later the space became fully funded by the university. The space collaborates with other makerspaces in Tunisia, as well as several fab labs throughout Europe (Ben Rejeb interview). The space relies on the university to give students the training needed to use the makerspace equipment, for engineering production, in contrast to most other spaces that give workshops and informal oneon-one sessions. Unlike Egypt's university-based FabLab AUC, Tunisia's FabLab ENIT collaborates with other makerspaces.

\section{LEVEL1}

LEVEL1, established in September 2017 in Tunis, is both a makerspace and a co-working space. It focuses on helping makers in the gaming and video industry, with specific emphasis on 3D gaming, virtual reality (VR), and augmented reality (AR) — areas the founders believed were not being sufficiently addressed by the maker movement in Tunisia. LEVEL1's main aims are to enhance the culture of making in the areas of gaming and video, and to help makers gain access to these industries. The space provides VR and AR workshops for adults and students, as well as workshops for children to help them create their own applications and games. LEVEL1 is completely self-financed by one of the founding partners, who uses revenue from his amusement park company to sustain the space and to purchase the necessary tools (Bouslama interview).

\section{Fablab Casablanca}

Fablab Casablanca in Morocco was launched in 2014 after two makers attended a Fab Foundation event in Munich, Germany, and were inspired to replicate the fab lab model in their hometown of Casablanca. Fablab Casablanca is accredited by the Fab Foundation and emphasises a self-manufacturing, do-it-yourself culture, using computer-controlled machinery. The space is open to anyone who wants to use the tools and equipment for educational, commercial, or personal interests. The machines include laser cutters, a 3D printer, and various electronic tools. It is completely self-funded by one of its founders, based on revenues from a private computer chip company. It has strong ties within the maker community and provides free weekly training sessions. It hosts an association for entrepreneurs that encourages makers to scale their creations into businesses (Abouch and Kouska interview). 
Table 2: Makerspaces' core characteristics

\begin{tabular}{|c|c|c|c|c|}
\hline Name & $\begin{array}{l}\text { Year of } \\
\text { establish- } \\
\text { ment }\end{array}$ & $\begin{array}{l}\text { The physical space } \\
\text { (new v. upgraded) }\end{array}$ & $\begin{array}{l}\text { Type of } \\
\text { entity }\end{array}$ & Funding and income \\
\hline $\begin{array}{l}\text { Fab Lab } \\
\text { Egypt }\end{array}$ & 2012 & $\begin{array}{l}\text { Original location: } \\
\text { Upgraded from } \\
\text { personal garage } \\
\text { New location: New } \\
\text { space }\end{array}$ & $\begin{array}{l}\text { Communi- } \\
\text { ty-based }\end{array}$ & $\begin{array}{l}\text { Provision of paid B2B services; } \\
\text { user fees for space and machine } \\
\text { use; membership fees }\end{array}$ \\
\hline $\begin{array}{l}\text { Qafeer } \\
\text { Maker- } \\
\text { space }\end{array}$ & $\begin{array}{l}2013 \\
\text { (closed in } \\
2019)\end{array}$ & $\begin{array}{l}\text { Upgraded within } \\
\text { existing co-working } \\
\text { space }\end{array}$ & $\begin{array}{l}\text { Communi- } \\
\text { ty-based }\end{array}$ & $\begin{array}{l}\text { Crowdfunding; user fees for space } \\
\text { and machine use; membership fees }\end{array}$ \\
\hline $\begin{array}{l}\text { Fab Lab in } \\
\text { New Cairo } \\
\text { (FLiNC) }\end{array}$ & 2015 & $\begin{array}{l}\text { Upgraded within } \\
\text { an existing private } \\
\text { company }\end{array}$ & $\begin{array}{l}\text { Communi- } \\
\text { ty-based }\end{array}$ & $\begin{array}{l}\text { Private funding; user fees for space } \\
\text { and machine use; membership fees }\end{array}$ \\
\hline $\begin{array}{l}\text { FabLab } \\
\text { AUC }\end{array}$ & 2017 & $\begin{array}{c}\text { Upgraded from } \\
\text { empty lab space at } \\
\text { AUC }\end{array}$ & $\begin{array}{l}\text { Universi- } \\
\text { ty-based }\end{array}$ & $\begin{array}{l}\text { University funding; user fees for } \\
\text { machine use; no membership fees }\end{array}$ \\
\hline $\begin{array}{l}\text { Karakeeb } \\
\text { Maker- } \\
\text { space }\end{array}$ & 2013 & $\begin{array}{l}\text { Upgraded space } \\
\text { within } \\
\text { cultural centre }\end{array}$ & $\begin{array}{l}\text { Communi- } \\
\text { ty- based }\end{array}$ & $\begin{array}{l}\text { Crowdfunding and private } \\
\text { funding; user fees for space and } \\
\text { machine use; no membership fees }\end{array}$ \\
\hline icealex & 2013 & New & $\begin{array}{l}\text { Communi- } \\
\text { ty-based }\end{array}$ & $\begin{array}{l}\text { Crowd funding; user fees for space } \\
\text { and machine use; membership fees }\end{array}$ \\
\hline $\begin{array}{l}\text { Alex } \\
\text { Hacker- } \\
\text { space }\end{array}$ & 2015 & New & $\begin{array}{l}\text { Communi- } \\
\text { ty-based }\end{array}$ & $\begin{array}{l}\text { Private funding; user fees for space } \\
\text { and machine use; no membership } \\
\text { fees }\end{array}$ \\
\hline $\begin{array}{c}\text { FabLab } \\
\text { ENIT }\end{array}$ & 2013 & $\begin{array}{l}\text { Built from scratch } \\
\text { on university } \\
\text { campus }\end{array}$ & $\begin{array}{l}\text { Universi- } \\
\text { ty-based }\end{array}$ & $\begin{array}{l}\text { Private funding and university } \\
\text { funding; user fees for space and } \\
\text { machine use; no membership fees }\end{array}$ \\
\hline LEVEL1 & 2017 & New & $\begin{array}{l}\text { Communi- } \\
\text { ty-based }\end{array}$ & $\begin{array}{l}\text { Private funding; user fees for space } \\
\text { and machine use; no membership } \\
\text { fees }\end{array}$ \\
\hline $\begin{array}{c}\text { Fablab } \\
\text { Casablanca }\end{array}$ & 2014 & New & $\begin{array}{l}\text { Communi- } \\
\text { ty-based }\end{array}$ & $\begin{array}{l}\text { Private funding; user fees for space } \\
\text { and machine use; no membership } \\
\text { fees }\end{array}$ \\
\hline
\end{tabular}




\section{Thematic findings}

We now present key findings that emerged from the qualitative data analysis in terms of five thematic areas:

- knowledge-sharing;

- innovation and product development;

- openness, collaboration, and innovation ownership;

- attitudes towards intellectual property (IP); and

- scaling.

\section{Knowledge-sharing}

Both informal and formal modes of learning are prevalent in all the makerspaces we studied. Peer-to-peer collaboration between users of the spaces is key to the spaces' community-of-practice attributes (according to the aforementioned Wenger et al. (2002) community of practice concept).

Fab Lab Egypt offers customised internship programmes for delivery of business-to-business (B2B) services to client and school programmes in science, technology, engineering, and mathematics (STEM) skills. This lab also offers a Maker Diploma course, which introduces the basic principles of making and prototyping. A dentist who was awarded his Maker Diploma from Fab Lab Egypt now 3D prints his moulds, improving the accuracy of his procedures (El Safty interview). The lab also offers a six-week technical internship, called "Maker Chef", to educators and hackers specifically, and presents interns with an opportunity to join Fab Lab Egypt's tech team (Maker Chef, 2016).

FLiNC's main focus is on teaching engineering-learning strategies so as to transform new makers into proficient makers (El Raffei interview). Conceptual design was prioritised, as it related to how people can think of a design for something to be produced. In addition, FLiNC provides process management workshops that people can add to their resumes (El Raffei interview).

FabLab AUC stresses learning-by-doing and designing-for-manufacturing. The lab's users are mostly engineering students, and the space aims to bridge the gap between a design idea and actual implementation or manufacturing. The lab has a technical team to help entrepreneurs who do not have a background in design (Shalaby and Ragab interview).

Alex Hackerspace places emphasis on providing its makers with "unconventional learning" via hands-on exposure to tools that can be used to create new products (E1 Shaer interview). The space offers courses in woodworking, metal welding, 3D printing, laser cutting, the use of $\mathrm{CNC}$ routers and other electronics, and the creation of handicrafts. Makers work and learn in groups, in a collaborative environment. The 
skills gained through the training courses were often cited on learners' resumes to help them in finding employment.

At Karakeeb Makerspace, many modes of learning are pursued, including mentoring and peer-to-peer learning experiences. Karakeeb offers an introductory safety and electronics course for anyone who visits the space for more than three hours, and Karakeeb staff provide help in operating the machinery. The learning at Karakeeb is said to transpire organically as a result of collaboration. Collaboration is said to be highly prevalent in the space, with the co-founders stating that people from different disciplines work better together and can learn from each other (Effat and Hassan interview).

icealex has the advantage of being situated within a larger technology innovation space, thereby connecting makers to entrepreneurial and marketing skills. The space offers a three-month internship, whereby interns experience different staff roles and get a chance to build a variety of skills. icealex emphasises a do-it-yourself ethic, whereby makers explore and learn through trial and error. The space also encourages peer-to-peer mentoring. It hosts monthly workshops targeting different skill sets for makers, in addition to offering entrepreneurship programmes for makers and artisans. Mentoring and technical assistance sessions are also offered.

Alex Hackerspace has an initiative whereby it purchases access to massive open online courses (MOOCs) that makers would otherwise not be able to afford on their own, and offers them for free. The course content is divided between the makers who signed up, and then each maker is responsible for teaching their fellow makers the content of the section they have been assigned. This allows the makerspace to cost-effectively introduce makers to a variety of necessary skills (El Shaer interview).

At FabLab ENIT, an emphasis is placed on the makers, who are almost exclusively students at the university, learning new skills through seeing the innovation processes present in each other's projects. FabLab ENIT also holds regular training sessions on 3D printing, digital manufacturing, and design-to-concept creation. At FabLab ENIT, makers learn from within their community of practice at the space. The space gives the makers the opportunity to work with expensive machines. They can access the machines easily and at a low cost, and can use the knowledge and skill sets gained in their later employment after university. FabLab ENIT holds regular training sessions on concept creation, design, digital manufacturing, and 3D printing, in which new makers learn the necessary skills from teachers or mentors. These skills have helped makers to secure employment after graduation. Several makers have used these skills to obtain internships and job opportunities. Makers report that job interviewers are very interested in the innovations that they have created at the fab lab (Ben Rejeb interview). 
At LEVEL1, the space caters largely to university students, including Master's and $\mathrm{PhD}$ students, who are looking for access to tools to complete their graduation projects. Makers at LEVEL1 have access to the regular co-working space, and a select few opt for the "VIP" option, whereby they have access to consultancy services, in return for producing a creation that benefits the community. LEVEL1 provides workshops in AR and VR for adult makers. There are also workshops for children, called Kids Hacker Labs, to develop children's skills in coding, software development, and application-building (Bouslama interview). LEVEL1's Bouslama explained that the software skills needed to enter the gaming market that are obtained through use of the regular and co-working space, as well as via attendance at various workshops, helps young entrepreneurs find employment in the gaming market - a market driven by young entrepreneurs (Bouslama interview).

At Fablab Casablanca, makers are able to supplement their knowledge of technology, electronics, and 3D printing through attendance at free weekly training sessions conducted by volunteers. Session topics are based on user preferences. The lab offers workshop spaces, provides several courses and workshops on how to use specific machines, and provides workshops on concept design and basic making concepts for beginner makers. The space welcomes both new and experienced makers ( $\mathrm{Fa}-$ blab Casablanca, n.d.). The directors of Fablab Casablanca stress that people work more in groups than individually, and learn an abundance of skills from each other (Abouch and Kouska interview).

At Qafeer Makerspace (which, as explained above, closed down in 2019, after our data collection), one-on-one assistance was the main learning tool offered, whereby the makerspace staff helped students while they worked on their projects. One of the co-founders served as the core support person for learning about product design, which was the main skill area covered by the space. Qafeer also offered courses, mostly design-related, which took up to 15 people, based on the demand for a certain topic. Due to time and resource constraints, Qafeer staff usually operated the 3D printer and other tools for the makers, most of whom were students. Therefore, although the makers were introduced to the tools available in the space and learned how they functioned, they seldom operated them on their own (El Zoughby interview).

\section{Innovation and product development}

Across the makerspaces studied, the most prevalent type of innovation found was social innovation, i.e., innovation based on seeking low-cost solutions to local problems and needs.

icealex supports makers in the use of human-centred design methodology to identify social innovations worthy of pursuit, i.e., to identify a challenge that is relevant to the community and then identify potentially viable solutions worthy of pursuit. icealex organises and hosts networking events and hackathons aimed at generating these 
viable ideas. One of icealex's makers has created a portable laser cutter, Risha Laser Cutter, which, coupled with its supplementary mobile app, allows users to draw their designs directly on their phones and laser-cut them using the portable cutter. This innovation is aimed at supporting marginalised communities with no access to this technology (Risha, n.d.). Another innovation produced at icealex is a water purification filter, which uses palm tree branches and stones. The filter was developed by a young woman whose parent suffers from kidney problems resulting from drinking contaminated water. This locally relevant, low-cost alternative works almost as well as the expensive industrialised version (Bastawy interview).

At Karakeeb Makerspace, it has been found that innovation usually occurs when makers set out to create solutions either to a problem in their everyday lives, or to ones they have witnessed in their community. A few years ago, makers at Karakeeb created an emergency lamp, powered by old mobile phones, to address Egypt's power cuts. This is a low-cost solution to a societal problem, and also an entrepreneurial endeavour. In the environmental sphere, Karakeeb co-founders and makers collaborated to create a smart trash bin that rewards the user for correctly separating trash, by posting to social media and praising the user's environmental effort (Effat and Hassan interview). One Karakeeb maker has started an accessory and decoration business based on products she designs and produces at the space.

At Fab Lab Egypt, one maker has used 3D printing to create a low-cost prosthetic hand. At FabLab ENIT, a maker has 3D-printed a prosthetic hand that incorporates robotics (Ben Rejeb interview). The Alex Hackerspace stated that the emphasis of the space is on providing an environment for the development of low-cost innovative solutions.

At FLiNC, users mainly produce low-cost products such as picture puzzles and woodwork. At FabLab AUC, where the makers are university students, we found that fidget-spinners were being created that could be sold for less than half their market price (Shalaby and Ragab interview).

\section{Openness, collaboration, and innovation orwership}

While the makerspaces studied all promote an openness ethos grounded in collaboration and sharing, our interviews found that the makers themselves sometimes find themselves in situations where they wish to claim and protect ownership in their innovation outputs. Most of the interviewees cited tensions that sometimes arise, among makers, between open collaboration and competition.

At Alex Hackerspace, the makers, before working on any group project, have to sign an agreement outlining the division of roles and percentage of work on each task in the project, so that everyone knows which part is assigned to them and what their 
share will be in any benefits from the final outcomes. This signed agreement is then used to settle ownership disputes (E1 Shaer interview).

At icealex, mediation, facilitated by the space, is used to settle innovation-ownership disputes. In an effort to prevent disputes from arising in the first place, icealex hosts regular workshops on the elements of the open collaboration (Bastawy interview).

At Fab Lab Egypt, innovation-ownership disputes typically arise when a maker feels a product might have commercial potential. While makers appreciate learning from each other, at the same time, there is also a degree of fear of collaboration due to the existence of a competitive culture. The disputes are resolved through agreements that assign innovation-ownership to the maker, or to more than one maker, working on the innovation. In general, lab management facilitates the reaching of an agreement but remains neutral, with the disputes ultimately resolved by the makers themselves. The lab directly intervenes in a dispute between members of the community only (1) if the dispute is seen as affecting the reputation of the space or the maker community as a whole; or (2) where the dispute involves one of the lab's staff members. At the time of our research, Fab Lab Egypt did not have a formal code of conduct-an absence which, according to the space's general manager, was problematic, i.e., it was problematic to have a shared culture, but no written rules governing it (El Safty interview).

At FLiNC, at the time of our research, there had been some innovation-ownership disputes between makers, but the disputes had not yet been resolved because the makerspace did not yet have a formalised dispute settlement mechanism in place. The lab was considering developing such a mechanism, and the FLiNC interviewee was of the view that the space could also benefit from having a guide on how to establish formal IP rights in one's innovation (E1 Raffei interview).

At Karakeeb Makerspace, the trend is towards collaboration and away from competitiveness, which can perhaps be partially attributed to the fact that the space is based in a cultural centre. The space's co-founders have found that people from a variety of different disciplines can work well together. At the time of our research, there had not yet been any innovation-ownership disputes and, accordingly, the space had not yet been required to play any role in such matters (Effat and Hassan interview).

At FabLab AUC, at the time of our research, there had not been any innovation-ownership disputes. The outputs of the makerspace are prototypes and not products, thus reducing the chances of disputes and making an ownership-dispute resolution structure unnecessary (Shalaby and Ragab interview). At FabLab ENIT, there had also not yet been any innovation-ownership disputes at the time of our research, and the space did not have a structure to address such matters. The space encourages its 
makers to work on an open collaborative basis, and so far makers had been willingly sharing their work and models (Ben Rejeb interview).

At Fablab Casablanca, the space does not view resolution of innovation-ownership disputes as part of its mandate, and all innovation creators are clearly given full ownership over their creations (Abouch and Kouska interview). LEVEL1 also leaves issues of innovation-ownership to the makers. The space had launched only very recently at the time of our research, and thus it remained to be seen whether significant issues of innovation ownership would arise (Bouslama interview).

At Qafeer Makerspace, innovation-ownership disputes were almost non-existent, apparently due to the small size of the group of makers and the nature of their outputs. The space was focused on introducing skills and augmenting university education, rather than generating inventions (E1 Zoughby interview).

\section{Attitudes towards intellectual property (IP)}

While innovation-ownership disputes arise in some of the makerspaces studied (as seen in the preceding section), due to users fearing that others may seek to copy their ideas and resulting products, these disputes and fears do not result in efforts to secure formalised IP protection, e.g., patents. The issues seem clearly to be matters of competition and secrecy, rather than formal IP protection. This lack of focus on formalised IP would appear to have several causes.

First, many of the users of the makerspaces studied tend to be individuals at a very early stage of joining the maker movement, who are still seeking knowledge about self-manufacturing tools. Second, the types of innovations taking place in the makerspaces generally do not warrant the consideration of formalised IP protection, i.e., the innovations produced are often incremental innovations that do not lend themselves to formalised IP protection. Third, IP issues are not well understood by most of the makers using the spaces studied. And fourth, efforts to secure formalised IP would run counter to the prevailing open collaborative ethos of the spaces.

As pointed out by Omar El Safty, general manager of Fab Lab Egypt, the physical setup of makerspaces, with their shared spaces and tools, forces makers to work together and collaborate. IP considerations, in the words of E1 Safty, are a "hassle in the maker community globally", leading to largely unnecessary debates regarding the benefits of open source approaches to innovation versus proprietary (i.e., IP-based) approaches. His experience is that makers usually do not like the idea of patents and other proprietary protection measures, and resort to protection only when a legal consultant advises them that this is the best option for their product. According to El Safty, out of the 15 start-ups that, at the time of our research, had businesses 
connected to their work at Fab Lab Egypt, only three had applied for patents for their innovations (El Safty interview).

Karakeeb Makerspace supports the open source ethos and tries to steer makers away from proprietary thinking (Effat and Hassan interview). icealex advocates for an open source culture, where everyone learns from each other and collaboration is key (Bastawy interview). At FabLab ENIT, users are all university students and innovation is not viewed as a competitive, business-oriented pursuit. This translates into a willingness by the student makers to share their models and work on an open source basis (Ben Rejeb interview).

\section{Scaling}

For some interviewees, scaling was seen as a necessary stage and an opportunity for entrepreneurs wishing to grow their businesses and penetrate markets based on their innovations. Other interviewees emphasised the fact that scaling's opportunities also come with associated risks, and that makers need to be wary of these risks before seeking to scale up. ${ }^{1}$

Fab Lab Egypt general manager El Safty believes that scaling of innovation represents both an opportunity and a threat for nascent entrepreneurs. Scaling is an opportunity for growth, and it is a desirable outcome from a business point of view. Nevertheless, many makers delve into projects too quickly without conducting the needed feasibility studies for scaling their innovations. This results in a growth rate that is not supported by the maker's capabilities and is potentially threatening to the entire project. Thus, "scaling is a double-edged sword that you must take step by step" (El Safty interview). To the extent that it is pursued, the key to scaling, according to El Safty, "is working on the horizontal by giving every maker the same attention, and not just makers who have products that we think are marketable or profitable" (El Safty interview).

FLiNC's manager El Raffei feels that scaling can be a threat because it requires additional sets of skills that are often beyond the capabilities of the founders of a start-up. Nevertheless, FLiNC does host workshops to promote the scaling of products (El Raffei interview).

Karakeeb Makerspace's Effat and Hassan argue that the key to scaling is not to focus on only one product. Instead, it is important to be involved in many innovative initiatives at the same time. The space sees its role as providing the necessary technical assistance and know-how. At the same time, at Karakeeb there are makers who primarily seek to create for the enjoyment and satisfaction of it, and who do not wish

1 For an in-depth treatment of approaches to innovation-scaling by makerspaces and other knowledge-based enterprises in African settings, see Open AIR (2020), Scaling Innovation: How Open Collaborative Models Help Scale African Knowledge-Based Enterprises. 
to burden themselves with thinking about scaling an innovation and establishing a business (Effat and Hassan interview).

icealex co-founder Bastawy sees scaling as a key and desirable outcome for makers working with products. icealex's aforementioned use of human-centred design methodology seeks, among other things, to enhance the potential for scalability. icealex seeks to encourage scaling by connecting its makers to the demand side of the market, where they can provide their innovations as meaningful solutions to existing challenges. For example, when the importing of Ramadan lanterns was restricted in Egypt, icealex makers produced them on a medium-scale, thereby filling a market gap during that season (Bastawy interview).

Fablab Casablanca's directors Abouch and Kouska believe scaling is a desirable outcome and, accordingly, their space aims to support makers in formalising and growing their innovations. The lab regularly informs its makers of competitions that can allow them to share their prototypes and to grow into enterprises. The role of the makerspace is to ensure that makers create a high-quality product or innovation on a small scale that will later enable the maker, if the maker so chooses, to scale the innovation independently of Fablab Casablanca (Abouch and Kouska interview).

Alex Hackerspace co-founder El Shaer views scaling as an opportunity for nascent entrepreneurs, but warns that scaling is not always desirable (El Shaer interview). The space's aforementioned purchase of MOOC access for its makers included MOOC content on the skills needed for entrepreneurship and scaling-up businesses, to ensure sustainable knowledge-sharing and scalability, according to the Alex Hackerspace co-founder (El Shaer interview).

At the time of our research, LEVEL1 Tunisia had not yet reached the stage where its makers were tackling the issue of scalability. However, co-founder Bouslama said that while he acknowledges that every business opportunity includes risks, he believes that scaling is an important opportunity for makers. A main aim of LEVEL1 is to provide a space where makers can develop their innovations to a point where they become more suited for entry into the market (Bouslama interview).

FabLab AUC co-founders Shalaby and Ragab see their makerspace as primarily seeking to aid makers in creating prototypes, without having a significant role to play in relation to scaling. Additionally, they were of the view that Egyptian entrepreneurs tend not to have a strong orientation towards scaling (Shalaby and Ragab interview).

FabLab ENIT Director Ben Rejeb believes that scaling is a great opportunity, and is usually the ultimate goal for nascent entrepreneurs. Accordingly, ENIT seeks to provide makers with the opportunity to test and develop their products to the point where they can enter the market. ENIT also aims to create more funding opportu- 
nities for innovation, such as via investment opportunities and crowd-funding (Ben Rejeb interview).

The Qafeer Makerspace Director felt that scaling was an opportunity and always a desirable outcome for nascent entrepreneurs. However, in the case of makers at Qafeer, scaling of an enterprise needed to be achieved through connections external to the makerspace. In cases where the scaling of an innovation from Qafeer led to the formalisation of an enterprise, the makers went beyond the makerspace to start-up accelerators in order to get the help they needed to establish their formal businesses (El Zoughby interview).

In terms of scaling the work of the makerspaces themselves, Fab Lab Egypt offers its paid B2B services in an effort to find a balance between having a community-based makerspace that is affordable for makers and at the same time scaling-up via an external source of revenue that does not affect the essence of the space (El Safty interview). A key scaling risk for a makerspace is, of course, that it may, in seeking scale, take on additional functions and obligations too rapidly, thus placing strain on already-stretched financial resources. Indeed, most of the spaces spoke of the need to access more funding. And, as mentioned above, one of the spaces studied, Qafeer Makerspace, closed down in 2019 due to financial difficulties.

Fab Lab Egypt also seeks to scale the national presence of the maker movement, through its FabLab on Wheels initiative, to which FLiNC also contributes. At the time of our research, FLoW had toured three Egyptian governorates, and was planning future visits to two more (El Raffei interview). The Alex Hackerspace interviewee also had a vision for scaling the Egyptian maker movement as a whole, calling for more support for existing makerspaces and for the introduction of the concept of making within formal educational structures (E1 Shaer interview).

\section{Conclusions}

It is clear from the findings generated by this study that the maker movement has significant momentum in Egypt, Tunisia, and Morocco. The movement has taken root in a relatively short period of time, in tandem with the changes in the region set off by the Arab Spring from 2011 onwards. There is clear evidence, based on the 10 makerspaces investigated, of dynamic approaches to knowledge-sharing, innovation, and scaling, all of which augur well for strengthening the spaces' communities of practice. At the same time, there is still a degree of fragility in the movement, with most of the spaces that we studied citing inadequate funding, and with one of the spaces, Qafeer Makerspace, closing down due to financial difficulties.

It is likely that the future sustainability of the makerspaces in Egypt, Tunisia, and Morocco will be reliant, to a great extent, on their ability to continue providing 
dynamic knowledge-sharing opportunities for users, via the continued offering of dynamic mixes of informal and formal learning opportunities of the kind outlined above in the research findings. Makerspaces across the countries under study have the potential to act as a bridge, connecting knowledge creation with entrepreneurship, for many young graduates of secondary or tertiary education as they confront the gap between what is taught in a classroom and what is needed in the job market-in line with the perspective of Van Holm (2017).

A second core element of the spaces' sustainability is likely to be their ability to evolve into increasingly vibrant hubs for social innovations that can be spun off, at or beyond the makerspaces, into job-creating enterprises. Our research findings found clear evidence of social innovation work at some of the spaces studied-e.g., at icealex (the portable Risha Laser Cutter, the water purification filter), at Karakeeb Makerspace (the emergency lamp powered by discarded mobile phones, the smart trash bin), and at Fab Lab Egypt (the 3D-printed artificial limb). These kinds of innovations likely hold the greatest promise for the makerspaces in their roles as prototyping, pre-incubation spaces for aspirant entrepreneurs.

Finally, there is a need for continued research into the dynamics and activities of makerspaces in Egypt, Tunisia, and Morocco. Among the makerspaces examined, it is clear that there is a diversity of approaches and models emerging, all of which require further investigation. In particular, further research will be needed in order to shed better light on linkages between makerspaces and entrepreneurship, and on the roles makerspaces can play in influencing socio-economic development. We have seen in the findings presented in this article that makerspaces are highly dynamic entities, and the Egyptian, Tunisian, and Moroccan maker movements can be expected to evolve in myriad ways, in the years and decades to come, that will offer insights and lessons that can help inform policy and practice in the North African region and elsewhere in Africa and the Global South.

\section{References}

Alex Hackerspace. (n.d.) [Facebook page]. https://www.facebook.com/alexhackerspace/ Anderson, C. (2012). Makers: The new industrial revolution. Crown.

Armstrong, C., De Beer, J., Kraemer-Mbula, E., \& Ellis, M. (2018). Institutionalisation and informal innovation in South African maker communities. Journal of Peer Production (JoPP), 12, 14-42. http://peerproduction.net/wp-content/uploads/2018/07/ jopp issue12 vol1of3.pdf

De Beer, J., Armstrong, C., Ellis, M., \& Kraemer-Mbula, E. (2017). A scan of South Africa's maker movement. Open AIR Working Paper 9. Open African Innovation Research (Open AIR) network. https://openair.africa/a-scan-of-south-africas-maker-movement/

Dougherty, D. (2012). The maker movement. MIT Press Journal, 7(3), 11-14. https://doi.org/10.1162/INOV a 00135 
Ekekwe, N. (2015, May 29). Africa's maker movement offers opportunity for growth. Harvard Business Review. https://hbr.org/2015/05/africas-maker-movement-offers-opportunity-for-growth

ElHoussamy, N., \& Rizk, N. (2018). The maker movement across North Africa. Open AIR Working Paper 17. Open African Innovation Research (Open AIR) network.

FabLab AUC. (n.d.). [Facebook page]. https://www.facebook.com/FabLabAUC/

Fablab Casablanca. (n.d.). [Facebook page]. https://www.facebook.com/FABLAB.CASA/

Fab Lab Egypt. (n.d.). [Website]. https://fablabegypt.com

FabLab ENIT. (n.d.). [Facebook page]. https://www.facebook.com/Fab LabENIT/

Fab Lab in New Cairo (FLiNC). (n.d.). [Web page]. https://www.fablabs.io/labs/fablabnewcairo

FabLab on Wheels (FLoW).(n.d.). [Web page]. https://www.fablabs.io/labs/fablabonwheels Fablabs.io. (n.d.). [Website]. https://www.Fab Labs.io

Fab Foundation. (n.d.). Fab Foundation mission. http://www.fabfoundation.org/index.php/ about-fab-foundation/index.html

Good, T. (2013). Three makerspace models that work. American Libraries Magazine, 44(1-2). icealex. (n.d.). [Website]. http://icealex.com

icecairo. (n.d.). [Website]. http://www.icecairo.com

International Labour Office (ILO). (2016). World employment and social outlook 2016: Trends for youth. https://doi.org/10.1002/wow3.76

ILO. (2017). Youth and employment in North Africa: A regional overview. https://www.ilo.org/ africa/events-and-meetings/WCMS_577306/lang--en/index.htm_

LEVEL1 (n.d.). [Website]. http://www.level1hub.com/

Kamel, F. (2016). Mapping the landscape of entrepreneurial activities in North Africa. Unpublished manuscript. The American University in Cairo.

Karakeeb Makerspace (n.d.). [Facebook page]. https://www.facebook.com/karakeeb.co/

King, D. L., Adegboyega,B., Rozario,J., \& Pearce,J.M. (2014).Mobile open-source solar-powered 3-D printers for distributed manufacturing in off-grid communities. Challenges in Sustainability, 2(1), 18-27. http://dx.doi.org/10.12924/cis2014.02010018

Kraemer-Mbula, E., \& Armstrong, C. (2017). The maker movement in Gauteng Province, South Africa. Open AIR Working Paper 6. Open African Innovation Research (Open AIR) network. https://openair.africa/the-maker-movement-in-gautengprovince-south-africa/

Maker Chef. (2016). Maker Chef technical internship - Fab Lab Egypt. http://makerchef. Fab Lab-egypt.com/

Maker Faire Cairo. (n.d.). Maker Faire Cairo. http://makerfairecairo.com/

Makerspace. (n.d.). What's a makerspace? http://spaces.makerspace.com/

Open African Innovation Research (Open AIR). (2020). Scaling innovation: How open collaborative models help scale African knowledge-based enterprises. https://openair.africa/scaling-innovation-how-open-collaborative-models-help-scale-africas-knowledge-based-enterprises/

Qafeer Makerspace (n.d.). [Facebook page]. https://www.facebook.com/qafeermakerspace/ 
Risha. (n.d.). Risha laser cutter. [Facebook page]. https://www.facebook.com/RishaLaser/?ref=page internal

Rizk, N., E1 Said, A., Weheba, N., \& De Beer, J. (2018). Torwards an alternative assessment of innovation in Africa. Open AIR Working Paper 10. Open African Innovation Research (Open AIR) network. https://openair.africa/towards-an-alternative-assessment-of-innovation-in-africa/

Sheridan, K. M., Halverson, E. R., Litts, B. K., Brahms, L., Jacobs-Priebe, L., \& Owens, T. (2014). Learning in the making: A comparative case study of three makerspaces. Harvard Educational Review, 84(4), 505-531. https://doi.org/10.17763/ haer.84.4.brr34733723j648u

The American University in Cairo (AUC) (2017, May 2). Students launch region's first university FabLab at AUC. News@AUC. http://www.aucegypt.edu/news/stories/students-launch-regions-first-university-Fab Lab-auc

Van Holm, E. J. (2015). Makerspaces and contributions to entrepreneurship. Procedia - Social and Behavioral Sciences, 195, 24-31. https://doi.org/10.1016/j.sbspro.2015.06.167

Van Holm, E. J. (2017). Makerspaces and local economic development. Economic Development Quarterly, 311(2), 164-173. https://doi.org/10.1177/0891242417690604

Von Hippel, E. (1986). Lead users: A source of novel product concepts. Management Science, 32(7), 791-805. https://doi.org/10.1287/mnsc.32.7.791

Waldman-Brown, A., Obeng, G. Y., Adu-Gyamfi, Y., Langevin, S., \& Adam, A. (2014, July 20). Fabbing for Africa's informal sector. Timbuktu Chronicles. https://www.africanewshub.com/news/1698721-fabbing-for-africas-informal-sector

Wenger, E., McDermott, R. A., \& Snyder, W. (2002). Cultivating communities of practice: A guide to managing knowledge. Harvard Business Press.

Williams, C. C. (2014). Informal sector entrepreneurship. Background Paper for OECD Centre for Entrepreneurship, SMEs and Local Development. Organisation for Economic Co-operation and Development (OECD). https://www.oecd.org/employment/ leed/Background-Paper-PB-Informal-Entrepreneurship-final.pdf

Zoomaal (n.d.). [Website]. http://www.zoomaal.com

\section{Intervierws}

Abouch, Y., and Kouska, A., Directors, Fablab Casablanca. Interviewed by A2K4D research team, September 2017.

Bastawy, A., Director, icealex. Interviewed by A2K4D research team, October 2017.

Ben Rejeb, H., Director, FabLab ENIT. Interviewed by A2K4D research team, October 2017.

Bouslama, R., Founder, LEVEL1. Interviewed by A2K4D research team, October 2017.

Chafik, S., Maker, Fablab Casablanca. Interviewed by A2K4D research team, September 2017.

Effat, M. and Hassan, R., Co-Founders, Karakeeb Makerspace. Interviewed by A2K4D research team, October 2017.

E1 Raffei, M., Director, Fab Lab in New Cairo (FLiNC). Interviewed by A2K4D research team, May 2017.

E1 Safty, O., Director, Fab Lab Egypt. Interviewed by A2K4D research team, October 2017. 
E1 Shaer, A., Founder, Alex Hackerspace. Interviewed by A2K4D research team, October 2017.

E1 Zoughby, A., Director, Qafeer Makerspace. Interviewed by A2K4D research team, February 2017.

Faical, G., Maker, Fablab Casablanca. Interviewed by A2K4D research team, September 2017.

Kamal, O., Maker, Shisan and Maker Faire Cairo. Interviewed by A2K4D research team, July 2017.

Shalaby, A., and Ragab, M., Co-Founders, FabLab AUC. Interviewed by A2K4D research team, May 2017.

\section{Appendix: Interview Protocol: Semi-Structured Questions}

\section{About the makerspace (for makerspace director/staff)}

a. When did you first hear of the concept of a makerspace?

b When was this makerspace established?

c. Tell us about the model that this makerspace follows.

d. Was this makerspace built from scratch, or is it upgraded from a previous older space (like a library)?

e. Where any of the tools you purchased brand new? Or are they mostly refurbished unused products?

f. Did you receive financial support in purchasing these tools? If yes, from who? And how long will the support last?

g. Are there any charges incurred on the makers to cover costs, like using a 3D printer?

h. What is the gender ratio in your makerspace?

i. How is maintenance and repairs performed on certain tools within that makerspace? Is it done via a professional service or by makerspaces?

j. Do you collaborate with other makerspaces, locally or globally? If yes, how?

k. How are (can) linkages across informal enterprises (be) stimulated in various contexts?

\section{Creative processes and knowledge-sharing (for makerspace director/staff)}

a. What type of innovation takes place in this makerspace?

b. What type of learning occurs in this makerspace?

c. What type of skills (if any) are introduced to the makers?

d. Among those that attend and use the makerspace, do any of them learn skills that help them find employment later on?

e. If there are people working in groups, do they learn from each other? Or do they learn from a teacher or mentor?

f. What is the group size of people working on a single project?

g. How can makerspaces help attract new potential entrepreneurs? 
h. Are there any specific examples or cases where a product was created to solve a specific problem in your area?

i. Do people drop in at the last minute, or do they plan to come?

\section{IP and informality}

a. What, if any, are the specific IP-related solutions and unique challenges for scaling up informal businesses?

b. Have there been any social issues or arguments between makers regarding ownership? If so, how were they resolved? Were these issues resolved legally or through arbitration?

c. What rules govern the relationship between informal businesses and formal counterparts if and when they decide to engage?

d. Which online portals do you go to, to find 3D models to download?

e. Does the space play a role in deciding who owns specific inventions created there? Or is there no monitoring of the process?

f. Is there any assisted legal process for makers who wish to implement copyright their inventions?

\section{Scalability}

a. Does scaling of innovation represent an opportunity or a threat for nascent entrepreneurs, and how can makerspaces play a part in ensuring sustainable access to knowledge for all?

b. Is scalability a desirable outcome?

c. In cases where scalability leads to formalisation, are we dealing with the formalisation of the innovation itself or the formalisation of the "informal" entity?

d. How can we upscale informal innovation in a way that creates more informal innovation-“scaling out”?

e. Were there any products that were produced, which were eventually manufactured?

\section{Measuring innovation}

a. How can the innovation taking place in makerspace contexts be better accounted for and documented?

b. How can we measure the creative output of the maker and the informal entrepreneur?

c. Investigating specifically knowledge creation within the sphere of the maker, the informal entrepreneur and the formal entrepreneur: can we assess the openness of innovation? How? 